\title{
THE CAUSAL LINK IN INTEGRAL RISK THEORY: REMOVAL, FLEXIBILITY OR RE-READING?
}

\author{
O NEXO DE CAUSALIDADE NA TEORIA DO RISCO INTEGRAL: AFASTAMENTO, \\ FLEXIBILIZAÇÃO OU RELEITURA?
}

\section{Gilberto Fachetti Silvestre}

Professor at Federal University of Espírito Santo (UFES); Ph.D in Private Law at Pontifical Catholic University of São Paulo (PUC/SP); Master's degree in Civil Procedural Law at Federal University of Espírito Santo (UFES); Lawyer.

E-mail: gilberto.silvestre@ufes.br

Lorenzo Caser Mill

Law student at Federal University of Espírito Santo (UFES); Scientific Initiation Fellow at National Research Council (CNPq).

E-mail: lorenzo.cm@hotmail.com

Recebido em: $11 / 02 / 2020$

Aprovado em: 28/08/2020

\begin{abstract}
This is a research that investigated aspects related to causality in the scope of integral risk theory, the most extreme modality of objective civil liability. The research, of qualitative character and method, analysed fundamentals in the scope of the Brazilian literature and researched examples of application of the object in the special and supreme instances. It adopted the methodology of systematic review of the literature and of judged paradigms. The data obtained indicate that, based on the analysis of specific hypotheses accepted for the adoption of full risk, the causal link in Brazil is the result of a temperance of the theory of equivalence of conditions with the theory of the scope of the norm, which returns to the function of the violated legal norm and its scope of protection, ascertaining whether the harmful event attacks that normative sphere.
\end{abstract}

Keywords: Causal link. Integral risk theory. Conditio sine quæ non. Scope of the rule.

RESUMO: This is a research that investigated aspects related to causality in the scope of integral risk theory, the most extreme modality of objective civil liability. The research, of qualitative character and method, analysed fundamentals in the scope of the Brazilian literature and researched examples of application of the object in the special and supreme instances. It adopted the methodology of systematic review of the literature and of judged paradigms. The data obtained indicate that, based on the analysis of specific hypotheses accepted for the adoption of full risk, the causal link in Brazil is the result of a temperance of the theory of equivalence of conditions with the theory of the scope of the norm, which returns to the function of the violated legal norm and its scope of protection, ascertaining whether the harmful event attacks that normative sphere.

Palavras-Chave: Nexo de causalidade. Risco integral. Conditio sine qua non. Escopo da norma. Revista de Direito Brasileira | Florianópolis, SC | v. 26 | n. 10 | p. 424-440 | Mai./Ago. 2020 
CONTENTS: Introduction. 1. Some philosophical notions of causality and how they influence the theory of civil liability. 2. Causality in the legal sense. 2.1. The individualistic theories. 2.2. The generalizing theory. 3. The causal link and the integral risk theory. 3.1. Removal, relaxation or re-reading of the causal link? 3.2. The integral risk submitted to the causal theories. 4. Examples of the causal link approach in cases of integral risk liability at the Superior Court of Justice (STJ) and the Federal Supreme Court (STF). Conclusion. References.

SUMÁRIO: Introdução. 1. Algumas noções filosóficas da causalidade e como influenciam na teoria da responsabilidade civil. 2. A causalidade em sentido jurídico. 2.1. As teorias individualistas. 2.2. A teoria generalizadora; 3. O nexo causal e a teoria do risco integral. 3.1. Afastamento, flexibilização ou releitura do nexo de causalidade? 3.2. O risco integral submetido às teorias causais. 4. Exemplos da abordagem do nexo de causalidade em casos de responsabilidade fundada no risco integral no Superior Tribunal de Justiça (STJ) e no Supremo Tribunal Federal (STF). Conclusão. Referências bibliográficas.

\section{INTRODUÇÃO}

This work aimed at revealing whether there is today a departure, a re-reading or a relaxation of the causal link within the "integral risk theory" in the Brazilian legal literature and in its extraordinary instances.

The risk society consists of a new reality that produces damages, especially related to the accelerated scientific and technological progress in the daily lives of individuals.

In concomitance with such scenario - and as a result of it -, there is an improvement in the civil liability in its traditional functions, meaning an absolute imputability of the reparative aspect, which is greatly represented by the integral risk theory - assuming the internalization of the inherent risks related to the activities deemed as "intolerable risk". The aforementioned theory, finally, has its main mode of operability in the influence on the causal link.

The investigations produced as a result a work that presents the bibliographic review of the Brazilian legal literature on the subject. Pari passu, a research of cases judged by the Superior Court of Justice and the Federal Supreme Court was conducted in order to demonstrate the applicability of what is defended in academic works.

In this sense, the research was developed as a qualitative approach. A review of the bibliography was carried out in order to deepen theoretically the concepts and theories of civilistics and procedure, explored specifically with regard to this subject. In addition, the research adopted the methodology of systematic review of judged paradigms, specifically resorting to the analysis of appeals in the superior and special instances.

The method used was the inductive one, seeking to establish a general reference based on the knowledge of a certain number of singular data, i.e., starting from singular data for the elaboration of a conclusion of generic nature.

The research, thus, intends to offer the operators of the Law the recent and current understanding of the Brazilian literature about the aspects related to the causal link in what concerns the integral risk theory in Brazil. And, with this, it intends to offer practical resources to the legal community for the operability of the matter in court. 


\section{SOME PHILOSOPHICAL NOTIONS OF CAUSALITY AND HOW THEY INFLUENCE THE THEORY OF CIVIL LIABILITY}

Causal theories in civil liability's field began to be outlined in the 19th century, seeking support in philosophical currents once idealized by notables such as Plato, ${ }^{1}$ David Hume and John Stuart Mill. ${ }^{2}$

Although Hans Kelsen presented some resistance to the dialogue between the causality of natural sciences and philosophy and legal causality - pointing out that legal causality has exclusively imputational purposes, ${ }^{3}{ }^{4}$ that is, it only aims at the achievement of the specific purposes of Law -, the meanings of cause and causality erected by philosophy ended up moulding to the particularities of Law, ${ }^{5}$ definitely impacting the construction of causal links supported by legal theory.

There are two distinct philosophical meanings conferred to causality: the first concerns a rational-deductive connection between two events, which infers a reason or a foundation for the production of a certain effect; and the second is an exclusively empirical connection, in which the effect is not rational or essentially deduced from what is supposed to be cause, but rather measured by means of a probability originating from a relationship of constancy in the succession of events.

Pablo Malheiros da Cunha Frota ${ }^{6}$ analyzed both reasonings and, thus, pointed out two elements that emerge from them: the univocal and infallible predictability of the effect arising from the cause; and the probability of the causal relationship linked purely to the unjustifiable repetition of the effects.

The rational-deductive theorethics attributed to Aristotle and Plato would ask for predictability through the essence, summarizing the movement of the world in "why" - i.e., causes - to be investigated in a logical way, "from a scientific cosmovision of nature". 7 Afterwards, René Descartes admitted knowledge only through deductive evidence modulated by a mathematical and causalistic rationalism, characterizing as infallible the relationship between cause and effect due to its uniformity.

According to João Paulo Capelotti, ${ }^{8}$ this Cartesian conception of a necessary and essential link between two events allows us to deduce a priori the effect from the cause, resembling the cause-effect relationship to the principle-consequence relationship, ${ }^{9}$ as a fundamental axiom of thought.

The empiricist philosophical construction has peremptorily contested the rationalist belief in the method and the unlimited capacity of reason. Experience and observation, in fact, would

\footnotetext{
${ }^{1}$ PLATÃO. Timeu-Crítias. Tradução do grego: Rodolfo Lopes. Coimbra: Centro de Estudos Clássicos e Humanísticos, 2011, pp. 34-37.

${ }^{2}$ MILL, John Stuart. A System of Logic, Ratiocinative and Inductive, being a connected view of the principles of evidence, and the methods of scientific investigation. New York: Harper and Brothers, 1882, pp. 235-266.

${ }^{3}$ KELSEN, Hans. Teoria Pura do Direito. Tradução de Luis Carlos Borges. Petrópolis: Vozes, 2012, pp. $151-153$.

${ }^{4}$ KELSEN, Hans. Teoria geral do direito e do Estado. Tradução de Luis Carlos Borges. $5^{\text {a }}$ ed., São Paulo: Martins Fontes, 1990, p. XXIX.

${ }^{5}$ FROTA, Pablo Malheiros da Cunha. Responsabilidade por Danos: imputação e nexo de causalidade. Curitiba: Juruá, 2014, p. 42.

${ }^{6}$ FROTA, Pablo Malheiros da Cunha. Responsabilidade por Danos: imputação e nexo de causalidade. Curitiba: Juruá, 2014, pp. 40-46.

${ }^{7}$ FROTA, Pablo Malheiros da Cunha. Responsabilidade por Danos: imputação e nexo de causalidade. Curitiba: Juruá, 2014, p. 40.

${ }^{8}$ CAPELOTTI, João Paulo. O nexo causal na responsabilidade civil: entre a certeza e a probabilidade. Dissertação (Mestrado em Direito) - Faculdade de Direito, Setor de Ciências Jurídicas da Universidade Federal do Paraná, 2012, p. 22.

${ }^{9}$ MORA, José Ferrater. Dicionário de Filosofia. Tradução de Roberto Leal Ferreira e Álvaro Cabral. São Paulo: Martins Fontes, 2001, p. 90.
}

Revista de Direito Brasileira | Florianópolis, SC | v. 26 | n. 10 | p. 424-440 | Mai./Ago. 2020 
consist of the only plausible forms of knowledge, since the human mind is a set of perceptions devoid of any causal relationship - i.e., of connection.

David Hume pointed out that causality would only be the human habit of associating distinct events because they were perceived together in the past. Experience would not allow a link between cause and effect, since these are diverse phatic events - and necessary relationships occur only between ideas. ${ }^{10}$ The regular succession of facts would only establish a relationship of contingency, not connection. João Paulo Capelotti ${ }^{11}$ writes that the Humian philosophy

não admitia a causalidade como um poder gerador de uma ligação necessária e essencial entre dois eventos. Refutava, pois, a dedução do efeito a partir da causa a priori. (...) recusa qualquer possibilidade de deduzir o efeito a partir da causa e, com isso, a existência de qualquer conexão necessária entre dois objetos. ${ }^{12}$

A notion of probability is thus referred to when establishing the relationship between different events. Bringing the question to the Law, this change of paradigm attempts to adapt causality to a new recorded dynamic of complexity, uncertainty and risk in social interactions, especially in economic activities marked by intense technical-scientific progress. In fact, it has become a gradually more costly task to delimit, with accuracy and scientific certainty, the causal link around a figure for liability purposes.

Thus, incorporating the aforementioned elements and signifiers, causality in the legal sense now gives rise to a complex causality, in which the causal process is not linear as conceived in physical-natural terms, but circular and interrelational. ${ }^{13}$ For Anderson Schreiber, ${ }^{14}$ "o nexo de causalidade natural ou lógico diferencia-se do jurídico, no sentido de que nem tudo que, no mundo dos fatos ou da razão, é considerado como causa de um evento pode assim ser considerado juridicamente", ${ }^{15}$ making a limitation of the juridical concept of cause imperative in order to proceed to civil liability, thus reaching the ends to which the Law was effectively disposed.

\section{CAUSALITY IN THE LEGAL SENSE}

The causality that interests the Law has been influenced by predictability and probability, and can be divided into causal theories that categorize two main orders: ${ }^{16}$ 1) the generalizing theory, which equates the causes with the conditions for the event and, therefore, is commonly called the theory of equivalence of conditions or conditio sine qua non; and 2) individualistic theories, represented by the theory of adequate causality, theory of direct and immediate damage and theory of the scope of the rule.

\footnotetext{
${ }^{10}$ HUME, David. Hume - Os Pensadores. 1996, pp. 60-61.

${ }^{11}$ CAPELOTTI, João Paulo. O nexo causal na responsabilidade civil: entre a certeza e a probabilidade. Dissertação (Mestrado em Direito) — Faculdade de Direito, Setor de Ciências Jurídicas da Universidade Federal do Paraná, 2012 , p. 24.

12 "Would not admit causality as a necessary and essential link between two events. It therefore refuted the deduction of the effect from the a priori cause. (...) it refuses any possibility of deducing the effect from the cause and with it the existence of any necessary connection between two objects".

${ }^{13}$ CUNHA, José Ricardo. Direito e complexidade. In: BARRETO, Vicente de Paulo (Coord.). Dicionário de Filosofia do Direito. São Leopoldo: Unisinos, 2006, pp. 231-232.

${ }^{14}$ SCHREIBER, Anderson. Novos Paradigmas da Responsabilidade Civil. $4^{\text {a }}$ ed., São Paulo: Atlas, 2012 , p. 55.

15 "The natural or logical causality connection differs from the juridical one, in the sense that not everything that, in the world of facts or reason, is considered as a cause of an event can thus be considered legally".

${ }^{16}$ FROTA, Pablo Malheiros da Cunha. Responsabilidade por Danos: imputação e nexo de causalidade. Curitiba: Juruá, 2014, p. 71.
}

Revista de Direito Brasileira | Florianópolis, SC | v. 26 | n. 10 | p. 424-440 | Mai./Ago. 2020 


\subsection{The individualistic theories}

Gisela Sampaio da Cruz writes that adequate causality is based on a judgment of probability, carried out by means of a posthumous prognosis that inquires whether, in a plurality of concauses, that particular cause is capable of producing the result from the common experience ${ }^{17}$ - i.e., in ordinary frequency ${ }^{18}$ - and not in an exceptional situation. It is this logic that has led USA jurisprudence, after decades of reluctance for "certainty", to condemn the tobacco industry to pay robust damages to smokers. ${ }^{19}$

As observed by João Paulo Capelotti, ${ }^{20}$ the support in strong probabilistic analysis and in past situations given by experience gives to adequate causality a clear empirical bias, a legacy of the philosophical current of the same name commanded by David Hume.

In general lines, therefore, for the effect to be adequate to the cause, the action from which the responsibility comes must be apt to cause the consummate damage, ${ }^{21}$ understanding such aptitude as the naturalistic and systematic repetition of the effect in similar circumstances. This notion is valid for both the positive and negative sections of the theory - the latter carries out the abstract judgment in the sense of verifying whether the event was totally indifferent to the production of the damage, which would only have occurred due to abnormal or extraordinary circumstances that acted in the specific case. ${ }^{22}$

Caitlin Sampaio Mulholland ${ }^{23}$ offers an example from German jurisprudence. A widow, faced with the death of her husband as a result of the war, applied for compensation in the face of the person who caused an automobile accident that resulted in the amputation of the leg of her deceased spouse. The allegation was that the amputation caused serious difficulties in locomotion and thus made it difficult for the victim to escape. The claim of authorship was not accepted because, although amputation figured as a condition for the event death - since it effectively imposed limitations for eventual escape - it could not be considered as its proper cause. After all, how many amputees in automobile accidents had as their ordinary fate the death in a war due to locomotion difficulties?

The theory of direct and immediate damage - or the theory of interruption of the causal link - expressly mentioned in art. 403 of the Brazilian Civil Code, shows itself to be even more restrictive in promoting imputation through the causal link. The sub-theory of necessity - a variable that eventually prevailed in the Brazilian legal literature, giving the emphasis to the aforementioned school $^{24}$ - points out that, if several conditions contribute to the harmful event, not all of them will give rise to the duty to indemnify, but only the one elevated to the category of necessary cause. ${ }^{25}$

${ }^{17}$ CRUZ, Gisela Sampaio da. O problema do nexo causal na responsabilidade civil. Rio de Janeiro: Renovar, 2005, pp. 64-65.

${ }^{18}$ MONTENEGRO, Antonio Lindbergh. Responsabilidade civil. $2^{\mathrm{a}}$ ed., Rio de Janeiro: Lumen Juris, 1996 , p. 336.

${ }^{19}$ FACCHINI NETO, Eugênio. A relativização do nexo de causalidade e a responsabilização da indústria do fumo a aceitação da lógica da probabilidade. In: Civilistica.com, ano 5, n. 1, 2016.

${ }^{20}$ CAPELOTTI, João Paulo. O nexo causal na responsabilidade civil: entre a certeza e a probabilidade. Dissertação (Mestrado em Direito) - Faculdade de Direito, Setor de Ciências Jurídicas da Universidade Federal do Paraná, 2012, p. 98 .

${ }^{21}$ CRUZ, Gisela Sampaio da. O problema do nexo causal na responsabilidade civil. Rio de Janeiro: Renovar, 2005, p. 67.

${ }^{22}$ MONTENEGRO, Antonio Lindbergh. Responsabilidade civil. $2^{\text {a }}$ ed., Rio de Janeiro: Lumen Juris, 1996 , p. 336.

${ }^{23}$ MULHOLLAND, Caitlin Sampaio. A responsabilidade civil por presunção de causalidade. Rio de Janeiro: GZ, 2010 , p. 161.

${ }^{24}$ POTHIER, Robert Joseph. Traité des obligations: selon les regles tant du for de la conscience, que du for extérieur. Paris: J. Rouzeaud-Montaut, 1764, pp. 176-194 apud REINIG, Guilherme Henrique Lima. A teoria do dano direto e imediato no Direito Civil brasileiro: análise crítica da doutrina e comentários à jurisprudência do STF sobre a responsabilidade civil do Estado por crime praticado por fugitivo. In: Revista de Direito Civil Contemporâneo, 2017, vol. 12, pp. 109-163, julho-setembro, p. 9.

${ }^{25}$ CRUZ, Gisela Sampaio da. O problema do nexo causal na responsabilidade civil. Rio de Janeiro: Renovar, 2005, pp. 101-104.

Revista de Direito Brasileira | Florianópolis, SC | v. 26 | n. 10 | p. 424-440 | Mai./Ago. 2020 
The cause is necessary to the damage because it is necessarily affiliated to it; it is exclusive cause because it operates per se, dispensed with other causes. ${ }^{26}$ It should also be emphasized that it is not time itself that determines liability for causing the damage, but logical closeness, since it is not the temporal distance between the illicit act and the damage that breaks the causal link.

The relationship between the theory in question and the notion of predictability embodied by the rationalists of the 16th century, who demand the bond of certainty that must unite the change from the initial state to the final state, an idea inspired in the Aristotelian sense of efficient cause, ${ }^{27}$ is evident. Such certainty, materialized in the necessity of the cause, endows the theory of direct and immediate damage with a more objective character than adequate causality: ${ }^{28}$ the latter is dependent on an abstract opinion about the usual harmful potential of the conduct.

On the other hand, there is the theory of the scope of the rule or the legal rule violated, conceived by Ernest Rabel, spread by Ernst von Cæmmerer and perhaps accepted by the jurisprudence of the Bundesgerichtshof. The theory delimits legal causality in the midst of a harmful event "por meio da interpretação da norma cujo suporte fático se estabelece (ou não) com a ocorrência do evento danoso, ou seja, o conteúdo e o fim desta normativa é que determinam a causalidade adequada e a imputação das responsabilidades pelo dever de reparar". ${ }^{29}$ The court must return to the function of the violated legal rule and its scope of protection, ascertaining whether the harmful event assaults that normative sphere. According to Gisela Sampaio da Cruz, "quando o ilícito consiste na violação de regra imposta com escopo de evitar a criação de um risco irrazoável, a responsabilidade estende-se somente aos eventos danosos que sejam resultado do risco do qual a conduta é vedada". 31

Guilherme Reinig adds that the theory of the scope of the rule extracts from the assumption of causality, without extirpating it, certain issues that are better resolved in a case-bycase plan of investigation, ensuring the final congruence between the rule of conduct violated and the so-called "primary injury", which makes liability possible. By reference to paragraph 823 , I and II of the Bürgerliches Gesetzbuch, he elucidates that the investigation of the scope of the rule is linked to a selection of tutelable interests, instigating the judgment to ascertain whether the damage is in the sphere or scope of protection of the violated rule. ${ }^{32}$

The application of this theory is convenient to a scenario of environmental damage, repeatedly related to the integral risk theory. Patrícia Faga Iglesias Lemos says that the theory has the merit of moving away from the phatic approach, seeking the legal causal link in the violated rule, taking into account the typical difficulties of the environmental issue such as distance, the multiplicity of incident factors, the problem of time for the occurrence of damage and even the lack

\footnotetext{
${ }^{26}$ ALVIM, Agostinho. Da inexecução das obrigações e suas consequências, p. 380-381, apud DA CRUZ, Gisela Sampaio. O problema do nexo causal na responsabilidade civil. Rio de Janeiro: Renovar, 2005, p. 103.

${ }^{27}$ CAPELOTTI, João Paulo. O nexo causal na responsabilidade civil: entre a certeza e a probabilidade. Dissertação (Mestrado em Direito) - Faculdade de Direito, Setor de Ciências Jurídicas da Universidade Federal do Paraná, 2012, p. 101.

${ }^{28}$ ALVIM, Agostinho. Da inexecução das obrigações e suas consequências, p. 388 apud DA CRUZ, Gisela Sampaio. O problema do nexo causal na responsabilidade civil. Rio de Janeiro: Renovar, 2005, p. 104).

${ }^{29}$ FROTA, Pablo Malheiros da Cunha. Responsabilidade por Danos: imputação e nexo de causalidade. Curitiba: Juruá, 2014, p. 96.

${ }^{30}$ CRUZ, Gisela Sampaio da. O problema do nexo causal na responsabilidade civil. Rio de Janeiro: Renovar, 2005, p. 87.

31 "When the illicit consists in the violation of a rule imposed with the purpose of avoiding the creation of an unreasonable risk, the responsibility extends only to the harmful events that are the result of the risk from which the conduct is prohibited".

${ }^{32}$ REINIG, Guilherme. O escopo de proteção da norma como critério limitativo da responsabilidade civil por ato ilícito: algumas contribuições ao Direito Civil brasileiro a partir do Direito Civil alemão. In: Revista de Direito Civil Contemporâneo, vol. 14, pp. 237-309, janeiro-março, 2018, p. 22.
}

Revista de Direito Brasileira | Florianópolis, SC | v. 26 | n. 10 | p. 424-440 | Mai./Ago. 2020 
of scientific certainty in several hypotheses. In this way, the author of a mere concause, who would not be able to achieve that harmful result, may be held responsible. ${ }^{33}$

Sometimes, the theory of the scope of the rule may end up excessively restricting liability: $v . g$., when even a conduct suitable for the production of a certain damage is not reputed to be the cause, because the damage produced would not have violated the sphere of protection of a specific rule. However, it must be considered that the investigation of the scope of the rule is primarily a question of interpretation, and as every question of interpretation takes place in a certain axiological and teleological context. Therefore, rules with a more defensive bias have the ability to prioritize the reparation of damage and thus extend civil liability to situations not usually protected by the usual causal theories - "adequate causality" and "direct and immediate damage". Guilherme Reinig understands that there would be "uma espécie de contínua atualização e ressignificação do escopo de proteção da norma", ${ }^{34}$ in order to make possible the integral reparation of the damage related to it. $^{35}$

\subsection{The generalizing theory}

The generalizing theory of equivalence of conditions was a thesis conceived by Maximiliano von Buri and inspired by “A System of Logic, Ratiocinative and Inductive”, by John Stuart Mill. ${ }^{36}$ The theory equates all conditions for damage with sufficient causes for its production - hence the equivalence between causes and conditions. Each condition gives rise to another condition, and the whole ultimately determines the damage, so that, if one of the conditions were removed, the result would not occur, ${ }^{37}$ legitimizing the aphorism causa est causati. Thus, since none of the conditions can be abstracted without altering the harmful result, the conditions are permeated by the determining notion of cause $\mathrm{e}^{38}$ of that event.

The feasibility of ascertaining any condition for liability purposes, substantially broadening the list of possible persons responsible for the consummated damage, would lead to the conclusion that the conditio sine qua non is the causal theory adopted by the legal literature sympathetic to the whole risk theory, ${ }^{39}$ whether in the context of environmental damage or nuclear damage (both constitute the most current hypotheses of application of this extreme aspect of the risk theory).

The classic example of an oil tanker that, hit by a very violent storm on the coast, ends up sinking and dumping the toxic content of its cargo on the seabed, causing serious damage to the fauna, flora and coastal populations of that region, would fit into this causal view due to the finding that the existence of cargo at sea - that is, something attributable to the oil company - was a condition for the storm to act and, thus, for the disaster to be outlined.

The issue is a change in the causal paradigm, no longer looking for a probability or predictability of that conduct to cause damage. After all, how many oil tanker voyages result in a chemical spill at sea?

\footnotetext{
${ }^{33}$ LEMOS, Patrícia Faga Iglecias. Meio ambiente e responsabilidade civil do proprietário: análise do nexo causal. $2^{\mathrm{a}}$ ed., São Paulo: Revista dos Tribunais, 2012, pp. 164-165.

34 "A kind of continuous updating and resignification of the scope of protection of the norm".

${ }^{35}$ REINIG, Guilherme. O escopo de proteção da norma como critério limitativo da responsabilidade civil por ato ilícito: algumas contribuições ao Direito Civil brasileiro a partir do Direito Civil alemão. In: Revista de Direito Civil Contemporâneo, vol. 14, pp. 237-309, janeiro-março, 2018, p. 22.

${ }^{36}$ MILL, John Stuart. A System of Logic, Ratiocinative and Inductive, being a connected view of the principles of evidence, and the methods of scientific investigation. New York: Harper and Brothers, 1882, pp. 235-266.

${ }^{37}$ LEMOS, Patrícia Faga Iglecias. Meio ambiente e responsabilidade civil do proprietário: análise do nexo causal. $2^{\mathrm{a}}$ ed., São Paulo: Revista dos Tribunais, 2012, p. 146.

${ }^{38}$ NORONHA, Fernando. Direito das obrigações. 4ª ed., São Paulo: Saraiva, v. 1, 2013, pp. 615-616.

${ }^{39}$ CARVALHO, Daniela Marques de. À procura de uma teoria de causalidade aplicável à responsabilidade civil ambiental. In: Revista de Direito Ambiental, vol. 62, pp. 11-54, Abr-Jun, 2011, p. 6.

Revista de Direito Brasileira | Florianópolis, SC | v. 26 | n. 10 | p. 424-440 | Mai./Ago. 2020
} 
Restricting the analysis of cause to the view of adequate causality or of direct and immediate damage, i.e., looking purely at the presence of the two fundamental elements of individualistic theories, it would not be possible to protect the victims of damage related to activities of extreme risk and social gravity entirely and adequately.

\section{CAUSAL LINK AND THE INTEGRAL RISK THEORY}

In this research, it was necessary to investigate the presence of the causal link in the integral risk theory and to assess how this causal link fits into causal theories.

\subsection{Removal, flexibility or re-reading of the causal link?}

There is no consensus in the Brazilian legal literature on the definition and contours of liability based on the integral risk theory, being sometimes called aggravated civil liability, sometimes even confused with the theory of administrative risk. In this sense, writes Sergio Cavalieri Filho: ${ }^{40}$

Na responsabilidade fundada no risco integral, o dever de indenizar é imputado àquele que cria o risco, ainda que a atividade por ele exercida não tenha sido a causa direta e imediata do evento. Bastará que a atividade de risco tenha sido a ocasião, mera causa mediata ou indireta do evento, ainda que este tenha tido por causa direta e imediata fato irresistível ou inevitável, como a força maior e o caso fortuito. Em outras palavras, o dano não é causado diretamente por uma atividade de risco, mas seu exercício é a ocasião para a ocorrência do evento. ${ }^{41}$

It is seen that the change of perspective in relation to the causal link is pointed out as a singularity of the theory, dispensing with its analysis under the perspective of the direct and immediate damage, extendable also to the adequate causality. It does not occur a "discarding" or "removal" of the causal link, ${ }^{42}$ but a redirection of the optics under which it is examined.

Moreover, removal would not even be possible from both natural and legal causality. According to John Stuart Mill, any event or conduct without which, on an abstract level, this result would not occur is considered efficient for the production of the result. And this is entirely consistent with the natural prism of causality, since, for example, in a purely naturalistic analysis, one could not consider the cause of a mining tailings dam rupture to be a simple Law class at university. From a legal perspective, liability based on legal causality without reasonable normative valuations, such as attributing to a mining company the breaking of a dam far from its area of operation and belonging to another mining company, would also not be acceptable.

Atilio Anibal Alterini ${ }^{43}$ points out that "a ressarcibilidade do dano principia por pressupor que seja juridicamente atribuível a outro sujeito; e tem um limite objetivo que o circunscreve em quanto reparável". ${ }^{44}$ And for the assessment of causality and consequent liability, Annelise

\footnotetext{
${ }^{40}$ CAVALIERI FILHO, Sergio. Programa de Responsabilidade Civil. 11 a ed., São Paulo: Atlas, 2014 , p. 184.

41 "In liability based on integral risk, the duty to indemnify is imputed to the one who creates the risk, even if the activity exercised by him was not the direct and immediate cause of the event. It is enough that the activity of risk was the occasion, a mere mediata or indirect cause of the event, even if the latter had as a direct and immediate cause an irresistible or inevitable fact, such as force majeure and fortuitous case. In other words, the damage is not directly caused by a risky activity, but its exercise is the occasion for the occurrence of the event".

42 See DE PAULA, Carolina Bellini Arantes. As excludentes de responsabilidade civil objetiva. São Paulo: Atlas, 2007, p. 53.

${ }^{43}$ ALTERINI, Atilio Anibal. Responsabilidad civil. Buenos Aires: Abeledo-Perrot, 1974, n. 7, p. 20.

44 "The reparability of the damage begins by assuming that it is legally attributable to another subject; and has an objective limit that circumscribes it in how much reparable".
}

Revista de Direito Brasileira | Florianópolis, SC | v. 26 | n. 10 | p. 424-440 | Mai./Ago. 2020 
Monteiro Steigleder ${ }^{45}$ calls attention to the observance of natural laws without which the damage would not occur and also to normative criteria, which translate valuation options: "a identificação da causa de um dano implica juízos de valor, informados pelo Direito, em que se fazem escolhas, fundadas em critérios tais como adequação social, periculosidade da atividade, proximidade temporal entre ação e a omissão e o dano, probabilidade etc." ${ }^{46}$ Therefore, the theory of integral risk could not reject such valuations in such a way as to simply remove the causal link altogether, i.e., in such a way as not to require any relationship between the damage and the entity to whom the duty to indemnify is attributed. In fact, the damage must be strictly connected and related to the risk activity carried out ${ }^{47}$ and which promoted all the means and conditions capable of consuming the damage.

Well then. The adoption of a new perspective in relation to causality implies the flexibility of this institute, with a gradual loss of rigour in its assessment in order to ensure to the victims the maximum compensation for the damages suffered. ${ }^{48}$

In fact, adequate causality and direct and immediate damage, based on predictability or probability, are more restrictive. According to Anderson Schreiber, the judicial authorities have been hesitant to give proof of the causal link the same harsh treatment given to the once necessary demonstration of guilt, preferring to navigate through more or less broad theoretical options before a laconic legislation on the matter. ${ }^{49}$

However, this should not mean a discretionary, even technical, on the part of the courts, without any dogmatic appreciation or respect for minimum causal delimitations in the natural and legal fields. By the way, Anderson Schreiber correctly points out that many decisions are handed down in the absolute absence of a causal connection from the point of view of any of the doctrinally recognized theories, several times superimposing political and ideological factors on good technique. ${ }^{50}$

\subsection{The integral risk theory submitted to the causal theories}

Integral risk effectively becomes familiar with - and seems to be anchored in - the theory of conditio sine qua non, since the robustness of all conditions as unavoidable causes of damage gives the judge a wide range of possibilities of imputation. By the idea, everything - commissive or omissive acts, advantages gained etc. - that, once removed from the causal chain, preventing the production of the harmful result may be qualified as a cause, adopting a process of elimination or addition of the antecedents ex post facto.

The hardened demonstration of the link between a conduct and the damage it causes is replaced by the tenuous link between the existence of risks pertinent to a certain activity, which may generate harmful situations, and the materialization of the damage. ${ }^{51}$ It is enough for the enterprise to create a "harmful circumstance" 52 that is intolerably costly to the social fabric.

\footnotetext{
${ }^{45}$ STEIGLEDER, Annelise Monteiro. Responsabilidade Civil Ambiental: as Dimensões do Dano Ambiental no Direito Brasileiro. $2^{\text {a }}$ ed., Porto Alegre: Livraria do Advogado, 2011, p. 171.

46 "The identification of the cause of a damage implies value judgments, informed by the Law, in which choices are made, based on criteria such as social adequacy, dangerousness of the activity, temporal proximity between action and omission and the damage, probability etc.".

${ }^{47}$ CAVALIERI FILHO, Sergio. Programa de Responsabilidade Civil. $11^{\mathrm{a}}$ ed., São Paulo: Atlas, 2014 , p. 184.

${ }^{48}$ SCHREIBER, Anderson. Novos paradigmas da responsabilidade civil. $4^{\text {a }}$ ed., São Paulo: Atlas, 2012 , p. 78.

${ }^{49}$ SCHREIBER, Anderson. Novos paradigmas da responsabilidade civil. $4^{\mathrm{a}}$ ed., São Paulo: Atlas, 2012 , p. 66.

${ }^{50}$ SCHREIBER, Anderson. Novos paradigmas da responsabilidade civil. $4^{\mathrm{a}}$ ed., São Paulo: Atlas, 2012 , pp. 66-67.

${ }^{51}$ DE CARVALHO, Daniela Marques. Â procura de uma teoria de causalidade aplicável à responsabilidade civil ambiental. In: Revista de Direito Ambiental, vol. 62, pp. 11-54, Abr - Jun, 2011, p. 6.

52 Pablo Malheiros da Cunha. Responsabilidade por Danos: imputação e nexo de causalidade. Curitiba: Juruá, 2014, p. 262.
}

Revista de Direito Brasileira | Florianópolis, SC | v. 26 | n. 10 | p. 424-440 | Mai./Ago. 2020 
This causal conception favors the victim in face of the increase in the number of potential responsible and finds support in the natural causality, ${ }^{53}$ which validates it in the legal sphere. Its disuse by Brazilian courts and those of other countries is justified in the teratologies hypothetically generated by reasoning, especially in the hypothesis of ad infinitum regression in the causal chain.

Such regression, depending on the size expansionism and without the tying of the principle of typicality characteristic of the Criminal Law, ${ }^{54}$ would lead to the possibility of responsibility of the manufacturer of a truncheon in case of injury perpetrated by any individual, after all, the manufacture of the truncheon was undeniably a condition for the aggression to be viable.

If the implications of liability were to be taken too far by attributing an infinite number of causes to an injury, the conditio sine quae non would tend to make every man responsible for all the evils that afflict humanity. ${ }^{55}$

Therefore, according to Anderson Schreiber, a temperance of the theory of equivalence of conditions is necessary for it to be feasible to relate it to civil liability based on integral risk. This model would be nothing new, since in Italy, for example, literature and jurisprudence have not inflexibly supported one or another thesis on causality, using the combination of the appropriate theory of causality and the theory of equivalence of conditions. ${ }^{56}$

In fact, such temperance must be given to the causal theory of the scope of the rule, which is justified by the interpretation of the provisions relating to the two currently accepted hypotheses of application of full risk: nuclear damage and environmental damage. Although the equivalence of the conditions has the capacity to impute the damage to any entity or individual involved in the causal chain of consummation of the damage, the theory of the scope of the standard determines whether the damage maculates the protective purposes of the legal standard and directs the civil liability to the one in charge of the risk activity. This is the first and indispensable condition for the harmful event.

Take the case of nuclear damage. The first legal regulation regarding liability for nuclear damage was Rule $n^{\circ}$ 6.453/1977, which observed some limitations and some exclusions. Article 4, by inferring that the nuclear installation operator's liability is independent of fault, already indicates a predilection for objective liability, highlighting the exclusions provided for in articles 7 and 8 . In other words, it would be a responsibility based on the risk created or the administrative risk, as defended by Rui Stoco, Toshio Mukai and Mírian Barreta Palla. ${ }^{57}$

The scenario changes from the 1988 Constitution of the Republic, more specifically with paragraph "d" of item XXIII of art. 21, which expressly dealt with liability for nuclear damage, stipulating that "civil liability for nuclear damage is independent of the existence of fault". Although it may appear to be just another provision of objective civil liability based on theories of risk - a kind of "reinforcement" of what was already preposterously established in infraconstitutional legislation -, this conclusion would be illogical on the basis of a systematic interpretation of the system.

Sergio Cavalieri Filho ${ }^{58}$ explains that this was an option of the constituent legislator for a regime of more severe liability for nuclear damages, since the Constitution already provides for a

\footnotetext{
${ }^{53}$ FROTA, Pablo Malheiros da Cunha. Responsabilidade por Danos: imputação e nexo de causalidade. Curitiba: Juruá, 2014, p. 75.

${ }^{54}$ SCHREIBER, Anderson. Novos paradigmas da responsabilidade civil. $4^{\text {a }}$ ed., São Paulo: Atlas, 2012 , p. 57.

55 AYNÈS, Laurent; MALAURIE, Philippe. Droit civil: les obligations. Paris: Cujas, 1990, n. 46, p. 74 apud PEREIRA, Caio Mário da Silva. Responsabilidade Civil. 12 ${ }^{\mathrm{a}}$ ed., Rio de Janeiro: Forense, 2018, p. 109.

${ }^{56}$ SCHREIBER, Anderson. Novos paradigmas da responsabilidade civil. $4^{\mathrm{a}}$ ed., São Paulo: Atlas, 2012 , p. 66.

${ }^{57}$ PALLA, Mírian Barreta. Da responsabilidade civil por danos ambientais durante o transporte marítimo de petróleo. In: Revista de Direito Privado, vol. 44, pp. 168-222, Out-Dez, 2010, p. 185; STOCO, Rui. Tratado de responsabilidade civil: doutrina e jurisprudência. São Paulo: Revista dos Tribunais, 2007, pp. 1.006 e 1.228; MUKAI, Toshio. Direito ambiental sistematizado. Rio de Janeiro: Forense Universitária, 2007, p. 72.

${ }^{58}$ CAVALIERI FILHO, Sergio. Programa de Responsabilidade Civil. $11^{\mathrm{a}}$ ed., São Paulo: Atlas, 2014, p. $195-196$.
}

Revista de Direito Brasileira | Florianópolis, SC | v. 26 | n. 10 | p. 424-440 | Mai./Ago. 2020 
regime of liability proper to the Public Administration ( $\$ 6^{\circ}$ of art. 37 ), which encompasses the exclusion of liability. Thus,

a responsabilidade pelo risco administrativo exige a relação de causa e efeito entre a atividade estatal e o dano, razão pela qual as causas de exclusão do nexo causal afastam a responsabilidade do Estado. Ao disciplinar a responsabilidade por dano nuclear, entretanto, a Constituição não exige nenhuma relação causal; fala simplesmente que a responsabilidade independe de culpa. Ademais, não haveria sentido para uma regra especial se tivéssemos a mesma disciplina geral da responsabilidade civil da Administração. ${ }^{59}$

If the integral risk of nuclear damage is adopted, Rule $\mathrm{n}^{\circ} 6.453 / 1977$ returns to the responsibility of the operator of the nuclear facility or the user of nuclear material that may have been granted. Items I, II and III of article 4 of Rule $n^{\circ} 6.453 / 1977$ establish "the exclusive civil liability of the operator of the nuclear installation" or of entities that have "effectively assumed the charges for nuclear material coming from a nuclear installation". Thus, while the theory of equivalence of conditions allows the imputation of any condition related to the nuclear damage that occurred, regardless of the occurrence of any of the usual exclusion of liability, the theory of the scope of the rule identifies the injury to the sphere of protection of the legal rule and guides the liability to the person in charge of the activity or of the nuclear material, translating into a valuation option of the system. This is something immanent to legal causality.

The same applies to environmental damage, in case of incidence of the integral risk theory in the understanding of Herman Benjamin, Nelson Nery Jr., Álvaro Mirra, Édis Milaré and Sergio Cavalieri Filho. ${ }^{60}$ The liability for environmental damage is objective, ${ }^{61}$ as provided in $\S 1$ of art. 14 of Rule $n^{\circ} 6.938 / 1981$, received by $\S \S 2$ and 3 of art. 225 of the Constitution of the Republic, and has as its emphasis the exercise of an activity that entails risks to the environment and to the health of the population, imposing on the entrepreneur the obligation of prevention (principle of prevention/precaution) and of internalization of such risks (principle of the polluter pays) in its productive process. $^{62}$

According to Herman Benjamin, if the event occurred in the course of or due to potentially degrading activity, it is up to the person responsible for it to repair any damage caused. The reparation, due to the particularities and the constitutional profile ${ }^{63}$ in which the environmental issue is involved, must be integral and due for the simple reason that the activity from which the damage occurred exists, whose owner fully assumes the risks arising from it. ${ }^{64}$ Thus, the traditional view of causalities is avoided, whether adequate or direct and immediate, in order to inadmit the exclusion of liability present in the theories of created risk and administrative risk.

The National Environmental Policy (Rule $n^{\circ} 6.938 / 1981$ ) and paragraphs $2^{\circ}$ and $3^{\circ}$ of art. 225 of the Constitution are a manifestation of the polluter pays principle, avoiding "that the

\footnotetext{
59 "Liability for administrative risk requires a causal relationship between the State's activity and the damage, which is why the causes of exclusion from the causal link exclude the State's liability. In disciplining liability for nuclear damage, however, the Constitution does not require any causal relationship; it simply states that liability is independent of fault. Moreover, there would be no point in a special rule if we had the same general discipline of civil liability as the Administration".

${ }^{60}$ CAVALIERI FILHO, Sergio. Programa de Responsabilidade Civil. 11 ${ }^{\text {a }}$ ed., São Paulo: Atlas, 2014, p. 194.

${ }^{61}$ BENJAMIN, Antonio Herman V. Responsabilidade civil pelo dano ambiental. In: Revista de Direito Ambiental, São Paulo, v. 3, n. 9, jan./mar., 1998, pp. 42-44.

${ }^{62}$ STEIGLEDER, Annelise Monteiro. Responsabilidade Civil Ambiental: as Dimensões do Dano Ambiental no Direito Brasileiro. $2^{\mathrm{a}}$ ed., Porto Alegre: Livraria do Advogado, 2011, p. 173.

${ }^{63}$ BENJAMIN, Antonio Herman V. Responsabilidade civil pelo dano ambiental. In: Revista de Direito Ambiental, São Paulo, v. 3, n. 9, jan./mar., 1998, p. 41.

${ }^{64}$ NERY JR., Nelson. Responsabilidade civil por dano ecológico e a ação civil pública. Doutrinas Essenciais de Responsabilidade Civil, vol. 7, pp. 823-844, Out/2011.
}

Revista de Direito Brasileira | Florianópolis, SC | v. 26 | n. 10 | p. 424-440 | Mai./Ago. 2020 
individual appropriation of environmental resources burdens the entire society and that the externalities caused by this appropriation are supported collectively. The regulations have framed the right to the environment as unavailable, protecting the injury of any damage inflicted on the related assets and signaling the duty to repair primarily to the polluter, who becomes the first payer. $^{65}$

Item IV of article $3^{\circ}$ of Rule $n^{\circ} 6.938 / 1981$ is categorical in defining as polluter also the indirect responsible for any environmental degradation, which makes the provision of item VII of art. 4 an axiological option of the order to establish the causal link between the damage and the risk activity undertaken.

Thus, the integral risk theory, in cases where the legal literature has accepted its incidence, bases causality on the theory of equivalence of conditions combined with the theory of the scope of the rule. This makes it preliminarily possible for any contributing factor to the damage to be qualified as cause and, after that, for the existence of the risk activity to be indicated as such, which guides the civil liability of the executor of the activity and, thus, protects the sphere of interest of the violated legal rule.

\section{EXAMPLES OF THE CAUSAL LINK APPROACH IN FULL RISK LIABILITY CASES AT THE SUPERIOR COURT OF JUSTICE (STJ) AND THE FEDERAL SUPREME COURT (STF)}

Previously, it should be informed that all the judgments to be analyzed relate to environmental damage, in Brazil, since the development of the integral risk theory, fortunately has not witnessed any other judicial case of nuclear damage. Some of the Superior Court of Justice (STJ) judgments concerning the Goiânia radiological accident mention only the presumption of causality for the granting of life pensions to firefighters and police officers who were in contact with the radioactive material ( $\mathrm{RMS} \mathrm{n} \mathrm{n}^{\mathrm{o}} 32.335 / \mathrm{GO}$ ).

The first example is Special Appeal $\mathrm{n}^{\circ}$ 1.374.284/MG, which dealt with the indemnity claim of a victim of floods resulting from the leakage of toxic mud from mining activity. Regarding material damages, the mining company claimed the occurrence of heavy rains in the region where the victim lives, which would in fact have caused the floods that inflicted the damage in question, thus breaking any causal link between the damage and the company.

Following a precedent established in Repetitive Appeal $\mathrm{n}^{\circ} 1.114 .398 / \mathrm{PR}$, the rapporteur, Minister Luis Felipe Salomão, stated that the liability for environmental damage is based on the theory of integral risk, being "o nexo de causalidade of fator aglutinante que permite que o risco se integre na unidade do ato que é fonte da obrigação de indenizar, de modo que, aquele que explora a atividade econômica coloca-se na posição de garantidor da preservação ambiental, e os danos que digam respeito à atividade estarão sempre vinculados a ela". 66

Next, the rapporteur of Special Appeal no 1.374.284/MG inferred that "constatou-se a existência de uma relação de causa e efeito, verdadeira ligação entre o rompimento da barragem com o vazamento de 2 (dois) bilhões de litros de dejetos de bauxita - corroborando para o transbordamento do rio Muriaé -, e o resultado danoso com a inundação da casa da recorrida contendo o referido mineral. Diante disso, constatado o nexo causal, não há mais, em sede de especial, como se discutir a ocorrência ou não de referido requisito". ${ }^{67}$

\footnotetext{
${ }^{65}$ STEIGLEDER, Annelise Monteiro. Responsabilidade Civil Ambiental: as Dimensões do Dano Ambiental no Direito Brasileiro. $2^{\mathrm{a}}$ ed., Porto Alegre: Livraria do Advogado, 2011, p. 211 e 172.

66 "The causal link is the binding factor that allows the risk to be integrated into the unity of the act that is the source of the obligation to indemnify, so that those who exploit the economic activity place themselves in the position of guarantor of environmental preservation, and the damage that relates to the activity will always be linked to it".

67 "The existence of a cause and effect relationship was verified, a true connection between the rupture of the dam with the leakage of 2 (two) billion liters of bauxite waste - corroborating the overflow of the Muriaé River - and the harmful

Revista de Direito Brasileira | Florianópolis, SC | v. 26 | n. 10 | p. 424-440 | Mai./Ago. 2020
} 
The reasoning undertaken, in order to identify a link between the damage and the risky activity and to base the causal link on that, refers to the qualification of all the conditions for the harmful result as causes. This idea is linked to the equivalence of conditions and, by means of a valuation option, the imputation of liability to the executor of the activity of extreme risk, the first condition for the indemnitable event.

Thus, liability exclusions are inadmissible, since only other conditions for the perpetration of such damage are shown: "não admite excludentes de responsabilidade, tais como o caso fortuito, a força maior, a ação de terceiros ou da própria vítima, posto que tais acontecimentos são considerados 'condições' do evento", ${ }^{68}{ }_{-}^{69}$

In same sense, Special Appeal $n^{\circ} 1.346 .430 / \mathrm{PR}$ involved the case of the rupture of a stretch of the Araucária-Paranaguá oil pipeline, technically called "OLAPA", belonging to Petrobrás and employed in the transportation of oil and oil products between the Getúlio Vargas Refinery and the Port of Paranaguá. The accident was characterized by the "abrupt landslide of a large mass of contiguous land, which exerted a violent traction force on the pipeline and caused it to rupture". Being an accident allegedly caused by a fact of nature, the question at issue in an extraordinary instance was whether there should be no imputation of liability to Petrobrás, given the supposed absence of a causal link between the company and the damage.

The rapporteur, Luis Felipe Salomão, again based his vote on Repetitive Appeal $n^{\circ}$ 1.114.398/PR and inferred that "the causal link remained demonstrated" in the exercise of the risk activity undertaken by Petrobrás as a result of the polluter pays principle, holding the company liable and failing to apply the exclusion of liability for force majeure. It is clear, therefore, that there is definitely no talk of "discarding" or "removing" the causal link for condemnation with emphasis on integral risk.

In the Federal Supreme Court (STF), this research revealed that the theory of integral risk has never been the subject of judgment, since this matter is generally restricted to the discussion of limitations of liability of infra-constitutional legislation, i.e., it is outside the functional jurisdiction of the supreme court.

However, it was perceived in this research that the judgment of Direct Unconstitutionality Action (ADI) $n^{\circ} 4.976 / \mathrm{DF}$ brought some comments on the difference between full risk and administrative risk that deserve highlighting.

The lawsuit sought, among other requests, the declaration of unconstitutionality of art. 23 of Rule $n^{\circ} 12.663 / 2012$ (General Law of the Cup). In thesis, the provision was incompatible with the general clause of responsibility of the Public Administration contained in $\S 6^{\circ}$ of art. 37 of the Constitution of the Republic. This is because the aforementioned provision would have adopted the integral risk of imputation of liability to the Government for damages related to the holding of the 2013 Confederations Cup and the 2014 World Cup.

The plea was dismissed on three main grounds: 1) the rule of art. 23 has an insurance fund, having the nature of a legal duty guaranteeing to the International Football Federation (FIFA), and not a form of vicarious liability; 2) $\S 6^{\circ}$ of art. 37 does not exhaust the modalities of liability to which the Administration is subject, admitting others more rigid in activities of extreme risk; and 3 ) art. 23 provides exclusions of liability, such as the fault of the victim or FIFA, something not admitted by the theory of integral risk.

result with the flooding of the defendant's house containing the aforementioned mineral. In view of this, once the causal link is established, there is no longer any special way to discuss the occurrence or non-occurrence of such requirement".

${ }^{68}$ STEIGLEDER, Annelise Monteiro, MILARÉ, Édis; MACHADO, Paulo Affonso Leme (Orgs.). In: Doutrinas essenciais de direito ambiental: responsabilidade em matéria ambiental. São Paulo: Revista dos Tribunais, vol. V, 2011, pp. 43-48.

69 "No liability exclusions, such as fortuitous circumstances, force majeure, the action of a third party or of the victim himself, are admissible, since such events are considered 'conditions' of the event". 
The vote of the rapporteur, Minister Ricardo Lewandowski, did not specifically address the issue of the causal link in the context of integral risk, but used the understanding of a Sergio Cavalieri Filho on the responsibility for nuclear damage to demonstrate the feasibility of holding the State liable in the face of the link between the activity of risk and the damage done, resting on this difference between integral risk and administrative risk.

The possibility of invoking exclusion of liability in administrative risk was treated as the main distinction in theory in relation to integral risk, which makes it possible to deduce that, although both require a link between state activity and the injury perpetrated, such a link occurs from different causal perspectives.

Thus, it can be said that the STF, although with a modest and tangentiated manifestation, does not speak of a departure from the causal link in the integral risk theory, in line with the position of the Superior Court of Justice.

\section{CONCLUSION}

This research focused on aspects of causality within integral risk theory, the most extreme modality of objective liability.

The legal-causal theories of direct and immediate damage and adequate causality, usually applied in the Brazilian civil liability system, have ballast in physical (or natural) and philosophical conceptions about causality, evidencing that juridical causality differs from natural causality: it is based on the latter, but uses axiological criteria to be delineated.

In this sense, adequate causality seeks to incorporate the empirical element of probability to establish imputation through a posthumous abstract judgment, while direct and immediate damage analyses predictability, more focused on a deductive rationalism, to determine with absolute certainty whether the damage is linked, a priori, to that conduct or that act.

The generalizing theory, known as conditio sine qua non, escapes these valuations based on the elements of probability and predictability, opting to consider efficient for the production of a harmful result any event or conduct without which, on an abstract plan, this result would not occur. All conditions are thus raised to the qualification of cause, in a verdict strongly based on natural causality.

The research found that the theory of integral risk, according to the legal literature already produced and also some recent decisions of the higher and supreme courts, does not rule out or remove the causal link to impute civil liability. But this would be inadmissible naturally and legally speaking.

In reality, the research has found that what we have is a re-reading of the causal link from another perspective than that of adequate causality and direct and immediate damage, something perfectly possible because of the perspective of equivalence of conditions, which also has a physical and philosophical basis.

From the analysis of the two accepted hypotheses of adoption of the integral risk environmental damage and nuclear damage -, it was found that the causal link in Brazil is the result of a temperance of the theory of equivalence of conditions with the theory of the scope of the rule, which returns to the function of the violated legal rule and its scope of protection, ascertaining whether the harmful event assaults that normative sphere.

Thus, it was preliminarily possible that any contributing factor to the damage be qualified as cause and, after, that the existence of the activity of risk be indicated as such - a valid option of the legal system -, guiding the civil liability to the executor of the activity and, thus, supporting the sphere of interests of the violated legal rule. 


\section{REFERENCES}

ALTERINI, Atilio Anibal. Responsabilidad civil. Buenos Aires: Abeledo-Perrot, 1974.

AYNÈS, Laurent; MALAURIE, Philippe. Droit civil: les obligations. Paris: Cujas, 1990.

BENJAMIN, Antonio Herman V. Responsabilidade civil pelo dano ambiental. In: Revista de Direito Ambiental, São Paulo, v. 3, n. 9, jan./mar., 1998.

MELLO, Marcos Bernardes de. Teoria do fato jurídico: plano da eficácia: $1^{a}$ parte. $3^{\mathrm{a}}$ ed., São Paulo: Saraiva, 2007.

CAPELOTTI, João Paulo. O nexo causal na responsabilidade civil: entre a certeza e a probabilidade. Dissertação (Mestrado em Direito) - Faculdade de Direito, Setor de Ciências Jurídicas da Universidade Federal do Paraná, 2012.

CARRÁ, Bruno Leonardo Câmara. A Responsabilidade da União na Lei Geral da Copa de 2014: uma análise sistemática. In: Revista do Instituto do Direito Brasileiro, Lisboa, ano 2, n. 11, 2013.

CARVALHO, Daniela Marques de. À procura de uma teoria de causalidade aplicável à responsabilidade civil ambiental. In: Revista de Direito Ambiental, vol. 62, pp. 11-54, Abr-Jun, 2011.

CAVAlIERI FILHO, Sergio. Programa de Responsabilidade Civil. 11ª ed., São Paulo: Atlas, 2014.

CRUZ, Gisela Sampaio da. O problema do nexo causal na responsabilidade civil. Rio de Janeiro: Renovar, 2005.

CUNHA, José Ricardo. Direito e complexidade. In: BARRETO, Vicente de Paulo (Coord.). Dicionário de Filosofia do Direito. São Leopoldo: Unisinos, 2006.

FACCHINI NETO, Eugênio. A relativização do nexo de causalidade e a responsabilização da indústria do fumo - a aceitação da lógica da probabilidade. In: Civilistica.com, ano 5, n. 1, 2016.

FACHIN, Luiz Edson. Nexo de causalidade como pilar essencial da responsabilidade civil. In: Soluções Práticas - Fachin, vol. 1, pp. 359-391, Jan/2012.

FROTA, Pablo Malheiros da Cunha. Responsabilidade por Danos: imputação e nexo de causalidade. Curitiba: Juruá, 2014.

HOBBES, Thomas. De Corpore. Tradução de M. Limongi e V. Moreira. Campinas: Unicamp, 2009.

HUME, David. Hume - Os Pensadores. 1996.

KELSEN, Hans. Teoria geral do direito e do Estado. Tradução de Luis Carlos Borges. $5^{\text {a }}$ ed., São Paulo: Martins Fontes, 1990. Teoria Pura do Direito. Tradução de Luis Carlos Borges. Petrópolis: Vozes, 2012. 
LEMOS, Patrícia Faga Iglecias. Meio ambiente e responsabilidade civil do proprietário: análise do nexo causal. $2^{\mathrm{a}}$ ed., São Paulo: Revista dos Tribunais, 2012.

MILL, John Stuart. A System of Logic, Ratiocinative and Inductive, being a connected view of the principles of evidence, and the methods of scientific investigation. New York: Harper and Brothers, 1882.

MONTENEGRO, Antonio Lindbergh. Responsabilidade civil. $2^{\mathrm{a}}$ ed., Rio de Janeiro: Lumen Juris, 1996.

MORA, José Ferrater. Dicionário de filosofia. Tradução de Roberto Leal Ferreira e Álvaro Cabral. São Paulo: Martins Fontes, 2001.

MUKAI, Toshio. Direito ambiental sistematizado. Rio de Janeiro: Forense Universitária, 2007.

MULHOLLAND, Caitlin Sampaio. A responsabilidade civil por presunção de causalidade. Rio de Janeiro: GZ, 2010.

NERY JR., Nelson. Responsabilidade civil por dano ecológico e a ação civil pública. Doutrinas Essenciais de Responsabilidade Civil, vol. 7, pp. 823-844, Out/2011.

NORONHA, Fernando. Direito das obrigações. 4ª ed., São Paulo: Saraiva, v. 1, 2013.

PALLA, Mírian Barreta. Da responsabilidade civil por danos ambientais durante o transporte marítimo de petróleo. In: Revista de Direito Privado, vol. 44, pp. 168-222, Out-Dez, 2010.

PAULA, Carolina Bellini Arantes de. As excludentes de responsabilidade civil objetiva. São Paulo: Atlas, 2007.

PEREIRA, Caio Mário da Silva. Responsabilidade Civil. 12ª ed., Rio de Janeiro: Forense, 2018.

PLATÃO. Timeu-Crítias. Tradução do grego: Rodolfo Lopes. Coimbra: Centro de Estudos Clássicos e Humanísticos, 2011.

POTHIER, Robert Joseph. Traité des obligations: selon les regles tant du for de la conscience, que du for extérieur. Paris: J. Rouzeaud-Montaut, 1764.

REINIG, Guilherme Henrique Lima. A teoria do dano direto e imediato no Direito Civil brasileiro: análise crítica da doutrina e comentários à jurisprudência do STF sobre a responsabilidade civil do Estado por crime praticado por fugitivo. In: Revista de Direito Civil Contemporâneo, vol. 12, pp. 109-163, julho-setembro, 2017.

. O escopo de proteção da norma como critério limitativo da responsabilidade civil por ato ilícito: algumas contribuições ao Direito Civil brasileiro a partir do Direito Civil alemão. In: Revista de Direito Civil Contemporâneo, vol. 14, pp. 237-309, janeiro-março, 2018.

SCHREIBER, Anderson. Novos Paradigmas da Responsabilidade Civil. $4^{\mathrm{a}}$ ed., São Paulo: Atlas, 2012.

STEIGLEDER, Annelise Monteiro. Responsabilidade Civil Ambiental: as Dimensões do Dano Ambiental no Direito Brasileiro. 2a ed., Porto Alegre: Livraria do Advogado, 2011. 
STOCO, Rui. Tratado de responsabilidade civil: doutrina e jurisprudência. São Paulo: Revista dos Tribunais, 2007.

VIOLANTE, Andrea. Responsabilità oggettiva e Causalità Flessible. Nápoles: Edizioni Scientifiche Italiane, 1999. 